\title{
Influence of age and medium on formation of epithelial cords in the rat fetal ovary in vitro
}

\author{
J. Prépin and N. Hida \\ Collège de France, Laboratory of Developmental Physiology, 11 place Marcelin-Berthelot, \\ 75231 Paris Cedex 05, France
}

\begin{abstract}
Summary. Fetal ovaries of $14 \cdot 5$-day-old rats were cultured for periods of up to 19 days in control medium or in medium conditioned by the preliminary culture of testes from fetal or young rats. In all ovaries, after 12 days of culture in either medium, epithelial cords were noted having an aspect identical to that of seminiferous cords present in fetal testes explanted at 14.5 days and also cultured for 12 days, i.e. the epithelial cords appeared in ovaries when there was no 'male' or testicular influence.

The appearance of histological preparations suggested that the disappearance of the germ cells might bring about a reorganization of the follicular cells in epithelial cords during the differentiation period of the first follicles. With ovaries cultured in conditioned medium, degeneration of the germ cells was more marked, follicles were rare and intra-ovarian cords were greater in number than in ovaries cultured in control medium. The ovaries thus transformed produced the anti-Müllerian hormone (AMH) although they lacked the "germinostatic activity" normally developed by testes of fetal or young rats. This germinostatic activity prevents the multiplication of oogonia when the testes and ovaries are co-cultured in vitro. The transformed ovaries therefore do not have all the functional capacities of fetal testes.
\end{abstract}

Keywords: ovarian cords; anti-Müllerian hormone; oocyte depletion; germinostatic activity; male influence; rat

\section{Introduction}

The development of epithelial cords or of tubular structures in mammalian embryonic ovaries cultured in vitro or transplanted in an adult male has often been reported, However, the conditions in which these formations have been observed and their interpretation as an eventual sign of masculinization have been the object of contradictory reports (see Burgoyne et al., 1984; Taketo et al., 1985, for reviews). None the less, for most authors the differentiation of these formations results from a 'male influence' the origin of which could be the adult testis (rat: Turner, 1969), the fetal testis (rat: Buyse, 1935; Moore \& Price, 1942; Holyoke, 1949; Macintyre, 1956; mouse: Turner \& Asakawa, 1964; Ozdzenski et al., 1976), anti-Müllerian hormone (AMH) (rat: Vigier et al., 1987) produced by the testes of the fetus or of very young rats (Picon, 1970; Donahoe et al., 1976) or even a non-determined organ of the adult male but which is not necessarily the testis (mouse: Taketo et al., 1984).

The very occasional presence of intra-ovarian epithelial cords has also been reported in embryonic ovaries grafted in adult females, i.e. in the absence of a 'male' or testicular environment (rat: Buyse, 1935; Moore \& Price, 1942; Holyoke, 1949).

The object of the present study was to verify whether epithelial cords or tubular structures could be differentiated in fetal rat ovaries in the absence of a male influence. 


\section{Materials and Methods}

Wistar CF rats (stock from the CNRS, France) were used. The age of the fetus was based on the estimated time of ovulation, i.e. $02: 00 \mathrm{~h}$ on the night of pairing (Jost \& Picon, 1970). Pregnant females were identified by palpation 13 or 14 days later.

The techniques of removal of explants and the in-vitro culture have been reported elsewhere (Prépin et al., $1985 \mathrm{a}, \mathrm{b}$ ). The sex of fetuses was determined by applying the sex chromatin test of the amniotic membrane (see Jost, 1972). The germ cells were counted in all serial sections, and so no correction factor was needed. The explants were cultured on grids coated with agar-agar in No. 3037 Falcon dishes. Each dish contained approximately $0.8 \mathrm{ml} \mathrm{CMRL}$ 1066 medium (Eurobio, Paris, France) to which was added $250 \mathrm{i} . \mathrm{u}$. penicillin $/ \mathrm{ml}$ (Specia, Paris, France) and $100 \mu \mathrm{g}$ streptomycin $/ \mathrm{ml}$ (Diamant, Paris, France). The medium was changed every 3 days. The cultures were maintained at $36 \pm 1{ }^{\circ} \mathrm{C}$ in a gas mixture composed of $95 \%$ air and $5 \% \mathrm{CO}_{2}$.

The conditioned media were prepared by immersing in the medium for 4 days testes or fragments of testis of approximately $1 \mathrm{~mm}^{3}$ removed from 16-20-day-old fetuses or young (4-64-day-old) rats. The characteristic activity of the conditioned media was to prevent the increase in the number of germ cells in the ovaries of 13.5-day-old fetuses cultured for 4 days. Very rarely, this number attained 7000 ("germinostatic effect") and no difference was observed in relation to the age of testes used to prepare the conditioned media, whereas on the average the number was 14000 when the ovaries had been cultured in a control medium (Prépin et al., 1985a, b).

After the culture period the explants were fixed in Bouin's fluid, and serial sections of $5 \mu$ mere stained with haematein-eosin.

After being cultured, the ability of the gonads, explanted at 14.5 days and cultured for 16 days in control or conditioned medium, to secrete AMH was evaluated using the classic biological test (Picon, 1969): the gonads were transferred to a new dish and cultured in a control medium for 4 days in contact with genital ducts removed from a female fetus of 14.5 days deprived of its ovaries. The inhibitory activity was judged by the condition of the Müllerian epithelium in the serial sections throughout the length of the duct. An inhibition scale having 3 degrees has been used: (I) slight - the diameter and the lumen of the ducts are reduced; occasionally there is a ring of fibroblasts; (2) moderate-the ducts have maintained an epithelial structure, but their diameter is narrow and the lumen is often absent; there are 2 or 3 rings of fibroblasts; (3) strong-the ducts are lacking in the serial sections (except in the posterior region of the genital tract) or reduced to a narrow cellular cord.

\section{Results}

\section{Development of ovarian histology}

The ovaries explanted at 14.5 days and cultured in vitro for 7 days in either medium acquired structures identical to those of 21 -day-old fetal ovaries. The only difference was that they were less voluminous (Fig. 1a).

After 12 days in vitro in control or conditoned media, the ovaries contained, other than a few primordial follicles, cords limited by a basal membrane (Fig. 1b). The periphery of the cords was composed of epithelial-type cells with nuclei arranged perpendicularly to the surface. Some aspects suggest that these cords could result from the fusion of follicles followed by a reorganization of the follicular cells after the degeneration of the oocytes (Fig. 1g). These cords, the diameter of which varied between 80 and $110 \mu \mathrm{m}$, were often curved and resembled seminiferous cords present in fetal rat testes explanted at 14.5 days and cultured for 12 days in control medium (Fig. 1c).

After 19 days of culture in control medium the ovaries contained, in addition to the cords already described, spherical structures composed of somatic cells polarized around the outside while the centre, formed of cells without any particular arrangement, contained 1 or 2 oocytes. These cords or spherical structures, on the average 8 for each ovary, were surrounded by 1 or 2 rings of fibroblastic cells. In addition to these formations, all the ovaries also contained 2 or 3 oocytes surrounded by a ring of follicular cells which was sometimes incomplete (Fig. 1f).

The ovaries cultured for 19 days in conditioned media were less voluminous than those cultured in control medium. They included about 20 cords and spherical structures (Fig. 1d) similar to those already described and, with two exceptions, had lost their oocytes (only 2 out of 22 ovaries cultured for 19 days contained follicles) (Fig. 1e). 

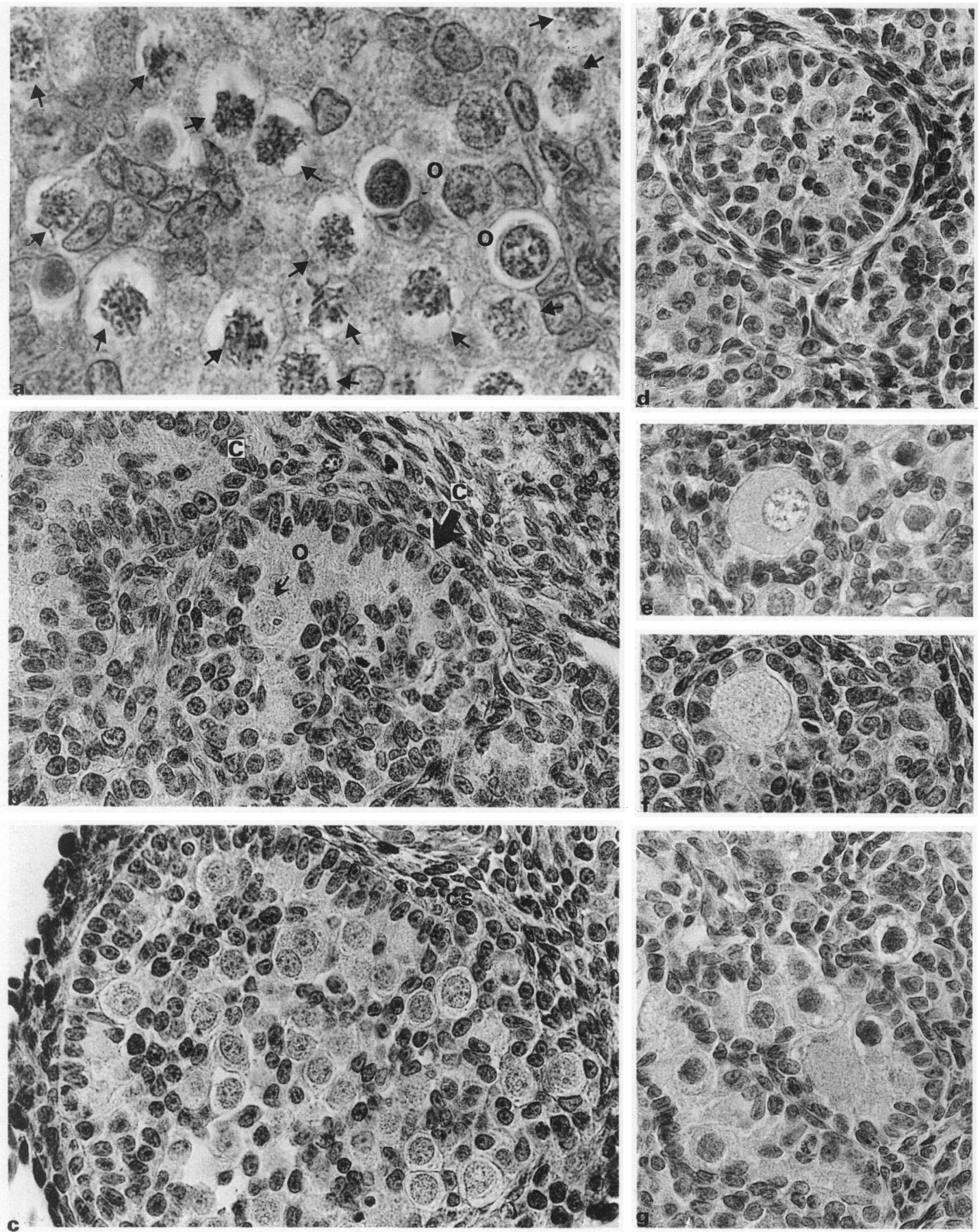

Fig. 1. Histological sections of gonads of 14-5-day-old fetuses cultured for various periods. (a) Ovary cultured for 7 days in control medium. There are oogonia $(\mathrm{O})$, but most germ cells have entered meiosis (arrow). $\times 550$. (b) Ovary cultured for 12 days in control medium. Two cords can be noted $(\mathrm{C})$. A germ cell is present $(\mathrm{O}) . \times 220$. (c) Testis cultured during 12 days in control medium. The seminiferous cords $(\mathrm{CS})$ are similar to the ovarian cords (see Fig. 1b). $\times 220$. (d) Ovary cultured for 19 days in conditioned medium. A spherical formation containing a germ cell is present. $\times 220$. (e) Ovary cultured for 19 days in conditioned medium. Exceptionally, it contains a follicle. $\times 220$. (f) Ovary cultured for 19 days in control medium. The ring of follicular cells surrounding the oocyte is incomplete. $\times 220$. (g) Ovary cultured for 19 days in control medium. This view suggests that the degeneration of the oocytes and the resulting disorganization of the follicles could lead to the formation of cords. $\times 220$. 


\section{Number of germ cells}

The variations in the number of germ cells, as a function of the duration of the culture and of the media, are shown in Fig. 2. This number decreased after the 3rd day. After the 12th day, in both types of medium, there were no longer any oogonia which had either degenerated or entered into meiosis. Even after 7 days of culture the ovaries grown in the conditioned medium had considerably fewer oocytes, and the difference increased during the days that followed. Thus, after 19 days those ovaries cultured in control medium contained on the average 425 germ cells while those cultured in the conditioned media contained many fewer, on average 45 , or none at all (4 out of 22 ovaries were sterile).

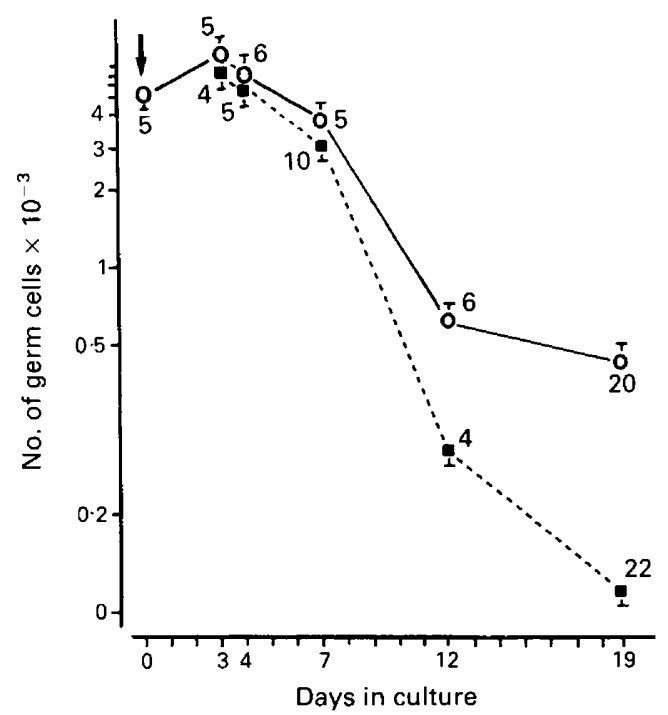

Fig. 2. Number of germ cells present in fetal ovaries explanted at 14.5 days and cultured for 3, 4, 7,12 or 19 days in a control $(O)$ or conditioned $(\boldsymbol{0})$ medium. The values are mean \pm s.e.m. for the no. of ovaries indicated near the points. The arrow indicates the average number of germ cells in the non-cultured 14.5-day-old ovaries.

\section{Anti-Müllerian activity}

The 9 ovaries cultured in the conditioned medium developed an anti-Müllerian activity which was greater than that of the 9 ovaries cultured in control medium (Table 1; Fig. 3).

Table 1. Number of Müllerian ducts slightly, moderately or strongly inhibited by fetal ovaries placed in prolonged culture in control or conditioned medium

\begin{tabular}{lcccc}
\hline & \multicolumn{3}{c}{ Inhibition } \\
\cline { 2 - 4 } & Slight & Moderate & Strong \\
\hline Control medium & 12 & 3 & 3 \\
Conditioned medium & 0 & 4 & 13 \\
\hline
\end{tabular}



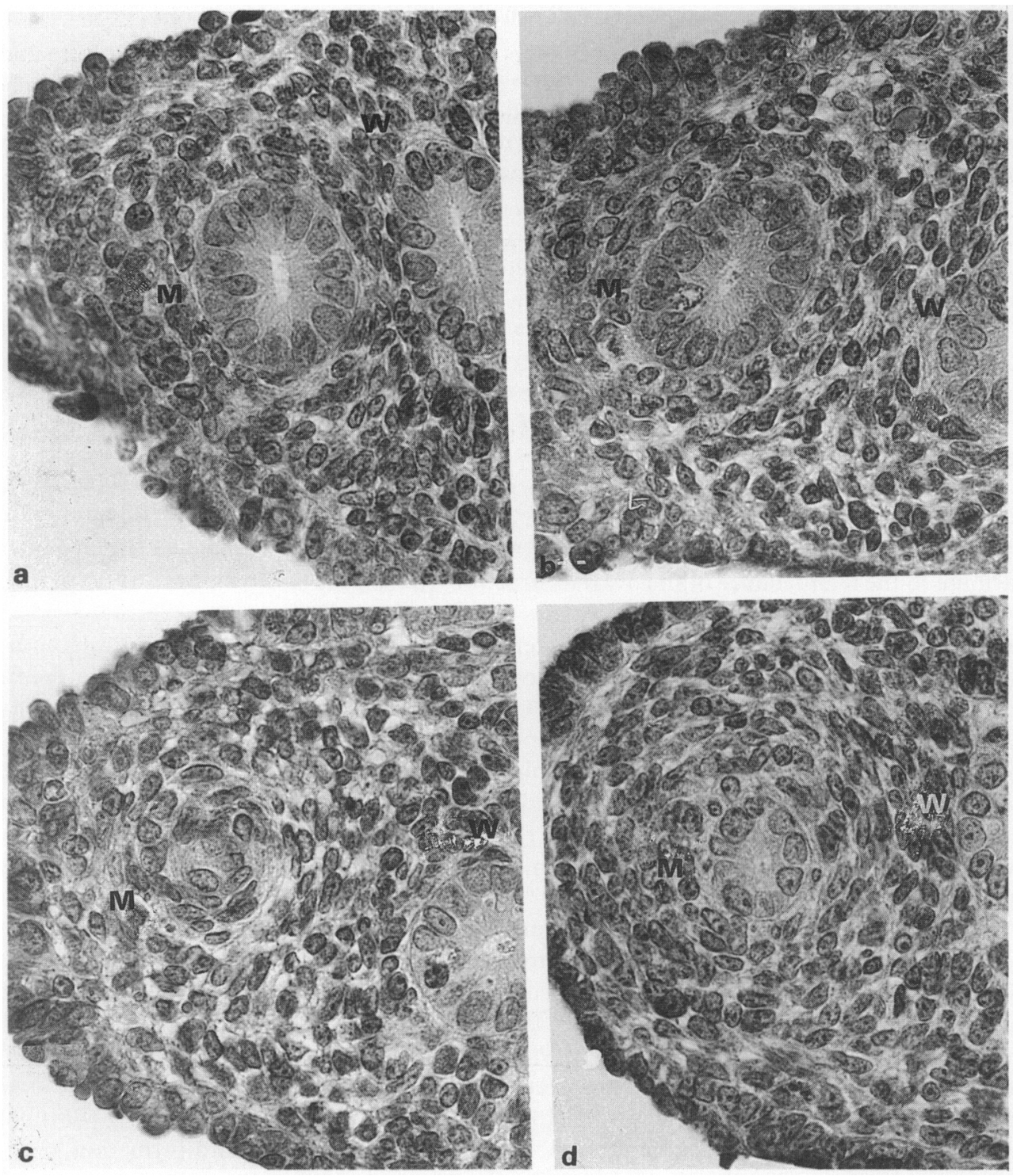

Fig. 3. Genital ducts $(m=$ Müllerian duct, $w=$ Wolffian duct $)$ of gonadectomized female fetuses explanted at 14.5 days and cultured for 4 days in control medium (a), in conditioned medium (b) or associated in vitro with ovaries explanted at 14.5 days and then cultured for 16 days in conditioned (c) or control (d) medium. The Müllerian ducts are well developed (a \& b) or inhibited $(c \& d) . \times 270$.

\section{Action on the proliferation of the oogonia in young ovaries}

Six ovaries explanted at 14.5 days and cultured for 16 days in control medium were then cocultured for 4 days with a pair of ovaries from a 13-5-day-old fetus with no contact between the two types of gonads. At the end of the culture period, in the pair of ovaries explanted at 13.5 days the number of germ cells was normal $(>10000)$. The transformed ovaries therefore had no "germinostatic activity" such as defined previously (Prépin et al., 1985b; Prépin \& Hida, 1989). 


\section{Discussion}

The ovaries explanted from 14-5-day-old fetuses and then cultured in vitro for at least 12 days in control medium, i.e. removed from all testicular influence, contained cords which resembled seminiferous cords present in testes of fetal rats removed at the same age and cultured during the same period of time. Previous data had shown that cords do not appear in ovaries cultured in vitro during 8 days in a control medium (Prépin et al., 1985a) or in a conditioned medium during 4 days (Prépin et al., 1985b). In addition, these transformed ovaries, tested after 16 days of culture which corresponds to 9 days post partum, had an inhibitory activity on the Müllerian ducts. According to Benhaim et al. (1982), this inhibitory capacity is not found in ovaries removed at 14.5 days and cultured for 9 days in vitro, while our results show that it is present in ovaries explanted at 14.5 days and cultured for 16 days. The inhibitory capacity therefore appears between 9 and 16 days in vitro. On the other hand, these same ovaries had none of the "germinostatic activity" that was shown by the testes of the fetus or young rats (Prépin et al., 1985a) or by the ovaries of 9-day-old female rats (Prépin \& Hida, 1989).

Some histological aspects suggest that the formation of cords could result from a reorganization of the follicular cell following the degeneration of the oocytes, as proposed by MacIntyre (1956), Ozdzenski et al. (1976) and Benhaim et al. (1982). Other data seem to indicate that the oocytes contribute to the maintenance of the ovarian structure. In fact, the disappearance of the germ cells of the embryonic ovaries of human XO fetuses (Singh \& Carr, 1966) or of rat fetuses exposed to busulphan during gestation prevents the differentiation of follicles or causes their disorganization (Forsberg \& Olivecrona, 1966; Vanhems \& Bousquet, 1971; Rateau, 1974). In the rat, epithelial cords develop from follicular cells (Forsberg \& Olivecrona, 1966; Vanhems \& Bousquet, 1971). The situation is similar in the early stages of ovaries cultured in medium conditioned by testes: the number of germ cells is low, the presence of follicles becomes exceptional and intra-ovarian cords develop in large numbers. If, on the other hand, the ovaries are placed in vitro in control medium the number of germs cells is large, the number of follicles is more important and there are fewer cords. The number of cords thus seems to be more or less inversely proportional to the number of germ cells.

In addition, the differentiation of the cords in those ovaries having few oocytes seems to take place during the period corresponding to the formation of the first follicles in vivo (lst or 2nd day post partum in rat), as has been suggested by experiments using in-vitro culture or ovarian fetal transplantation (MacIntyre, 1956; Mangoushi, 1975; Ozdzenski et al., 1976; Benhaim et al., 1982; Taketo et al., 1984, 1985; Taketo \& Koide, 1985), just as in bovine freemartins in which the appearance of seminiferous cords takes place at about the same time as when the follicles differentiate in controls (Jost et al., 1973). In ovaries cultured in vitro before the initiation of folliculogenesis in a hormone-free medium, there is no cord formation when the ovaries are cultured alone (Rivelis et al., 1976; Prépin et al., 1985a) or in the presence of fetal testes (Byskov \& Saxen, 1976; Stein \& Anderson, 1981; Evans et al., 1982; Prépin et al., 1985b). On the other hand, cords form in ovaries of fetal rats explanted at 14.5 days and cultured for 5 days in a medium to which bovine $\mathrm{AMH}$ has been added, i.e. before the initiation of folliculogenesis (Vigier et al., 1987). This last study suggests that AMH has an inductive role in the formation of intra-ovarian cords with the precocity of the appearance of the cords being in relation to the high concentration of $\mathrm{AMH}$ in the culture medium. However, if $\mathrm{AMH}$ is necessary for the formation of seminiferous cords, it is curious that the male fetuses of rabbits immunized against AMH develop normal testes while their Müllerian ducts remain intact: the action of the testicular AMH on the ducts had been prevented but not that of the formation of seminiferous cords (Tran et al., 1986). In our study, the ovarian primordia cultured over a prolonged period of time acquired an anti-Müllerian activity which, according to the hypothesis of Vigier et al. (1987), could play a role in the formation of the cords. During the normal differentiation of the ovary in vivo the secretion of AMH begins at a time when the oocytes are numerous and 
when the development of the follicles is already well advanced (Takahashi et al., 1986; Donahoe et al., 1987).

Finally the identification of the cords found in the present study as true fetal seminiferous cords was difficult because the transformed ovaries had no "germinostatic activity" such as has been shown to exist in isolated seminiferous cords from fetal testis (Prépin et al., 1985b).

We thank Professor A. Jost for invaluable discussions during the course of this work and the preparation of the manuscript.

\section{References}

Benhaim, A., Gangnerau, M.N., Bettane-Casanova, M., Fellous, M. \& Picon, R. (1982) Effects of H-Y antigen on morphologic and endocrine differentiation of gonads in mammals. Differentiation 22, 53-58.

Burgoyne, P.S., Ansell, J. D. \& Tournay, A. (1984) Can the indifferent mammalian XX gonad be sex-reversed by interaction with testicular tissue? In Serono Symposium on Development and Function of Reproductive Organs, pp. 23-29. Eds A. E. Shkol, B. Eckstein, N. Dekel, H. Peters \& A. Tsafriri. Ares-Serono Symposia, Roma.

Buyse, A. (1935) The differentiation of transplanted mammalian gonad primordia. J. exp. Zool. 70, 1-41.

Byskov, A.G. \& Saxen, L. (1976) Induction of meiosis in fetal mouse testis in vitro. Devl Biol. 52, 193-200.

Donahoe, P.K., Ito, Y., Marfatia, S. \& Hendren, W.H. (1976) The production of Müllerian Inhibiting Substance by the fetal, neonatal and adult rat. Biol. Reprod. 15, 329-334.

Donahoe, P.K., Cate, R.L., MacLaughlin, D.T., Epstein, J., Fullur, A.F., Takahashi, M., Coughlin, J.P., Ninfa, E.G. \& Taylor, L.A. (1987) Müllerian Inhibiting Substance: gene structure and mechanism of action of a fetal regressor. Recent Progr. Horm. Res. 43, $431-467$.

Evans, C.W., Robb, D.I., Tuckett, F. \& Challoner, S. (1982) Regulation of meiosis in the fetal mouse gonad. J. Embryol. exp. Morph. 68, 59-67.

Forsberg, J.G. \& Olivecrona, H. (1966) The effect of prenatally administered Busulfan on rat gonads. Biol. Neonate 10, $180-192$.

Holyoke, E.A. (1949) The differentiation of embryonic gonads transplanted to the adult omentum in the albino rat. Anat. Rec. 103, 675-699.

Jost, A. (1972) Données préliminaires sur les stades initiaux de la différenciation du testicule chez le rat. Archs Anat. microsc. Morph. exp. 61, 415-438.

Jost, A. \& Picon, L. (1970) Hormonal control of fetal development and metabolism. In Advances in Metabolic Disorders, vol. 4, pp. 123-184. Eds R. Levine \& R. Luft. Academic Press, New York.

Jost, A., Vigier, B., Prépin, J. \& Perchellet, J.P. (1973) Le développement de la gonade des freemartins. Annls Biol. anim. Biochim. Biophys. 13, 103-114.

MacIntyre, M.N. (1956) Effect of fetal testis on ovarian differentiation in heterosexual embryonic rat gonad transplants. Anat. Rec. 124, 27-46.

Mangoushi, M.A. (1975) Scrotal allografts of fetal ovaries. J. Anat. 120, 595-599.

Moore, C.R. \& Price, D. (1942) Differentiation of embryonic reproductive tissues of the rat after trans- plantation into postnatal hosts. J. exp. Zool. 90, $229-265$.

Ozdzenski, W., Rogulska, T., Batakier, H., Brzozowska, A., Rembiszewska, A. \& Stepinska, U. (1976) Influence of embryonic and adult testis on the differentiation of embryonic ovary in the mouse. Archs Anat. microsc. Morph. exp. 65, 285-294.

Picon, R. (1969) Action du testicule foetal sur le développement in vitro des canaux de Müller chez le rat. Archs Anat. microsc. Morphol. exp. 58, 1-19.

Picon, R. (1970) Modifications, chez le rat, au cours du développement du testicule, de son action inhibitrice sur les canaux de Müller in vitro. C. r. hebd. Séanc. Acad. Sci., Paris 271, 2370-2372.

Prépin J. \& Hida, N. (1989) Limitation du nombre des cellules germinales dans l'ovaire foetal de rat par des ovaires plus âgés, in vitro. C. r. hebd. Séanc. Acad. Sci., Paris 308, 61-64.

Prépin, J., Gibello-Kervran, C., Charpentier, G. \& Jost, A. (1985a) Number of germ cells and meiotic prophase stages in fetal rat ovaries cultured in vitro. $J$. Reprod. Fert. 73, 579-583.

Prépin, J., Charpentier, G. \& Jost, A. (1985b) Action du testicule foetal sur le nombre des cellules germinales de l'ovaire de foetus de rat, in vitro. C.r. hebd. Séanc. Acad. Sci., Paris 300, 43-47.

Rateau, J.G. (1974) Etude expérimentale de la maturation folliculaire et glandulaire des ovaires de rattes traitées par le Busulfan. C. r. Séanc. Soc. Biol. 168, 1168-1172.

Rivelis, C., Prépin, J., Vigier, B. \& Jost, A. (1976) Prophase méiotique dans les cellules germinales de l'ébauche ovarienne de rat cultivée in vitro en milieu anhormonal. C. r. hebd. Séanc. Acad. Sci., Paris 282, $1429-1432$.

Singh, R.P. \& Carr, D.H. (1966) The anatomy and histology of XO human embryos and fetuses. Anat. Rec. 155, 369-384.

Stein, L.E. \& Anderson, E. (1981) In vitro analysis of ovarian differentiation and the initiation of meiosis in the rat. Acta anat. 110, 189-205.

Takahashi, M., Koide, S.S. \& Donahoe P.K. (1986) Müllerian inhibiting substances as oocyte meiosis inhibitor. Molec. cell Endocrinol. 47, 225-234.

Taketo, T. \& Koide, S.S. (1985) Induction of testicular development in the fetal mouse ovary. Ann. N.Y. Acad. Sci. 438, 671-674.

Taketo, T., Merchant-Larios, H. \& Koide, S.S. (1984) Induction of testicular differentiation in the fetal mouse ovary by transplantation into adult male mice. Proc. Soc. exp. Biol. Med. 176, 148-153. 
Taketo, T., Koide, S.S. \& Merchant-Larios, H. (1985) Gonadal sex differentiation in mammals. In The Origin and Evolution of Sex, pp. 271-287. Eds H. O. Halvorson \& A. Monroy. Alan R. Liss, New York.

Tran, D., Picard, J.Y., Vigier, B., Berger, R. \& Josso, N. (1986) Persistence of Müllerian ducts in male rabbits passively immunized against bovine anti-Müllerian hormone during fetal life. Devl Biol. 116, 160-167.

Turner, C.D. (1969) Experimental reversal of germ cells. Embryologia 10, 206-230.
Turner, C.D. \& Asakawa, H. (1964) Experimental reversal of germ cells in ovaries of fetal mice. Science, N.Y. 143, 1344-1345.

Vanhems, E. \& Bousquet, J. (1971) Influence du Misulban sur le développement de l'ovaire du rat. Annls Endocrinol. 22, 753-761.

Vigier, B., Watrin, F., Magre, S., Tran, D \& Josso, N. (1987) Purified bovine AMH induces a characteristic freemartin effect in fetal rat prospective ovaries exposed to it in vitro. Development 100, 43-55.

Received 27 February 1989 